\title{
Tempeh \& Soybean Seed Coat: The Alternative Sources of Trans-Resveratrol as Neuroprotective Agents
}

\author{
Tempeh y Cubierta de Semillas de Soja: Fuentes Alternativas \\ de Trans-Resveratrol como Agentes Neuroprotectores
}

Yulia Irnidayanti \& Dias R. Sutiono

\begin{abstract}
IRNIDAYANTI, Y. \& SUTIONO, D. R. Tempeh \& Soybean seed coat: The alternative sources of trans-resveratrol as neuroprotective agents. Int. J. Morphol., 37(3):1164-1171, 2019.

SUMMARY: Resveratrol is a stilbenoid, a type of natural phenol, and a phytoalexin produced by several plants in response to injury or attack by fungi. The underutilization of soybean seed coat (Glycine max (L.) Merrill.) and tempeh, cheap Indonesia fermented food thus opens up a new opportunity for developing a Resveratrol-based medicine for Plants-Derived Neuroprotective Agents purposes. In this study, it was isolated from tempeh, ordinarily well-known as Indonesian soybean fermented food, and soybean seed coat. The finding of this compound was confirmed by TLC and HPLC analysis applying fluorescence detection. From this, the Rf-value for transresveratrol is 0.64 . As eluent, a mixture of chloroform, ethyl acetate, and formic acid $(2.5+1+0.1, \mathrm{v} / \mathrm{v})$ was selected. In addition, retention time for tempeh was 14.467 and for soybean seed coat was 11.977 . The extraction yield of resveratrol was $65.15 \%$ in tempeh and 55.35 $\%$ in soybean seed coat. Resveratrol isolated from Tempeh and Soybean seed coat gave prevents some reaction by modulating intracellular signaling pathways: protein kinase C (PKC), a family of 12 serine/ threonine kinases and providing a new lead molecule for neuroprotective affects in addition to has prevented cell death by apoptosis.
\end{abstract}

KEY WORDS: Trans-Resveratrol; Tempeh; Soybean seed coat; Neuroprotective

\section{INTRODUCTION}

Tempeh is a traditional fermented soybean and a staple food in Indonesia, where it serves as a cheap basic foodstuff with high nutrition, and it is consumed by most Indonesian people. It processes with germination and elicitation by R. oryzae. Germination, fermentation, heat treatments, and chemical and enzymatic hydrolysis are affected composition and content of the isoflavone in soybeans. Soybean are high in phytoestrogens and stilbenes (Ryung et al., 2010).

Resveratrol or 3,5,4'-trihydroxy-trans-stilbene is classified into phytoalexin, a phenolic compound in the stilbene family with trans- form which is being more recurrent in processing greater bioactivity (Wenzel \& Somoza, 2005) and is manufactured naturally by knotweeds, pine trees, grape vines, peanut plants, cocoa bushes, including: blueberries, raspberries, mulberries, cranberries, and bilberries (Jasinski et al., 2013). Consumption of resveratrol has precisely testified to the potentiality that affords protection against the brain-aging processes outstanding in Alzheimer's disease in rodent models
(Vingtdeux et al., 2010). Differently, one-year clinical trial of subjects with Alzheimer's disease showed that consuming 2 grams of resveratrol daily was well-tolerated and reduced some disease biomarkers in cerebrospinal fluid and blood, although other biomarkers and progressive dementia were unaffected (Turner et al., 2015). Other preliminary human studies indicated that short-term ingestion of resveratrol increased cerebral blood flow in normal subjects (Kennedy et al., 2010). Resveratrol is being studied for its potential to limit secondary damage after ischemic stroke or acute brain trauma. Other in vivo studies have reported after intraventricular injection of resveratrol for one week at 8-9month-old mice; the long-term memory formation and the LTP (long-term potentiation) induction from CA1 (Carbonic anhydrase 1) region of hippocampus were improved. The findings also demonstrate a role of resveratrol in cognition repairment via a microRNA-CREB (The cAMP Responsive Element Binding Protein)-BDNF (Brain Derived Neuro Trophic Factor) mechanism by which resveratrol regulates these processes, demonstrating its value as potential therapeutic target against CNS (Cell Nerve System) disorders 
in memory. Additional experiments suggest that RSV effects are likely to be mediated through reduced expressions of miR-134 and miR-124, which may in turn up-regulate CREB levels to subsequently promote BDNF synthesis. These findings demonstrate a role for RSV in cognition and a microRNA-CREB-BDNF mechanism by which RSV regulates these processes, demonstrating its value as a potential therapeutic target against CNS disorders in aging (Zhao et al., 2013). For the past 10 years, researches from all over the world have confirmed the involvement of 5-HT (5-hydroxytryptamine) receptor as serotonin receptor in neuroprotective effects of resveratrol which was also verified by an electrophysiological study (Lee et al., 2011). It was described that resveratrol is able to mediate current flow in the cell by regulating 5-HT3 receptor activity, possibly through interactions with the $\mathrm{N}$-terminal domain of serotonin receptor (Access, n.d.).

Resveratrol that was reported in twenty milligram is equivalent to approximately 200 to $1,000 \mathrm{~mL}$ of red wine, 1 $\mathrm{kg}$ of fresh grape (with skin), 2 litters of red grape juice, 5 litters of cranberry juice, $200 \mathrm{~g}$ of boiled peanuts or $2 \mathrm{~kg}$ of peanut butter. Again, one stilbene trans-resveratrol-3-Oglucoside was identified in low concentration in the sample without the fermentation process (Dueñas et al., 2012). The trans-resveratrol in grapes contained between 0.11 and 2.75 $\mathrm{mg} / \mathrm{L}$ (Piñeiro et al., 2006). Meanwhile, trans-resveratrol in the hydroalcoholic extract (HAE) of the husks of grapes contained $17.33 \mu \mathrm{g} / \mathrm{mg}$ (Boroski et al., 2016). Since peanut and peanut fermented food did not contain a huge number of resveratrol, thus the research was led to the findings of resveratrol from tempeh as Indonesian soybean fermented food and soybean seed coat as waste from tempeh making process. Due to the low cost and availability, they could be the best solution. In this study, the extraction yield of resveratrol was $65.15 \%$ in tempeh and $55.35 \%$ in soybean seed coat, meaning that the amount is sufficient to achieve the target.

The issue of the low availability of natural Resveratrol compound is an important one that should be solved in order to make the compound available in large quantity cheaply. The matter has been included in the strategic planning programs of the Indonesian Ministries of Commerce and Health in relation to an over-reliance on Resveratrol import for domestic consumption and development of safe alternative sources of Trans-Resveratrol, and a natural stilbenoids compound as Plants-Derived Neuroprotective Agents through finding a cheap source of natural Resveratrol.

Based on that, it is assumed that in the future resveratrol may be used in the treatment and prevention of neurodegenerative diseases since it has shown potential neuroprotective effects and it also prevents or slows down the progression of neurodegenerative diseases. This compound may have some reaction by modulating intracellular signaling pathways: protein kinase $\mathrm{C}(\mathrm{PKC})$, a family of 12 serine/threonine kinases (Qin et al., 2014). This finding is expected to improve intelligence via long-term potentiation (LTP) and neuroplasticity axon. Notwithstanding, the role of the trans-resveratrol from tempeh as Indonesian soybean fermented food and soybean seed coat to neuroprotective effects requires considerable further study.

\section{MATERIAL AND METHOD}

Material and Equipment: The trans-resveratrol standard was obtained from Sigma Chemical Co. The N-Hexane 95 $\%$ 2508-25LGL applied as support material was equipped by Ajax FineChem Pty.Ltd (New Zeland). For the extraction solvents, an Acetone of PT Multi Chemicalindo was employed. The TLC eluent were occupied from Chloroform 99.8 \% Global Chemie, Ethyl acetate $99.8 \%$ Bratachem, and Formic acid $85 \%$ Bratachem. The sample for TLC was diluted in Methanol from Ajax FineChem Pty.Ltd (New Zeland). The solvents employed were Aqua Pro Injection, and Acetonitrile 1.00030.2500 (HPLC grade) from Merck.

The tempeh and soybean seed coat, which were acquired commercially and hand-picked at Sentra Tahu Tempeh Primkopti (Lenteng Agung, South Jakarta, Indonesia), were used as samples. Soybean seed coat was dried in Oven model BCL-OF-11E (Lab Companion, Jeio Tech, Inc., Korea) for 5 h. $198 \mathrm{~g}$ of tempeh and dried soybean seed coat were milled separately using food processor BL101 PL (Miyako, Indonesia). The milled sample is macerated in $1980 \mathrm{~mL}$ Acetone for $180 \mathrm{~min}$. The suspensions were maintained on a rotary shaker model of WIS-30 of WiseCube (Witeg, Germany) at $180 \mathrm{rpm}$ for $120 \mathrm{~min}$. The suspensions were then sonicated for $5 \mathrm{~min}$ at frequency of $40 \mathrm{kHz}$ in HF Peak out 100 W Digital Ultrasonic Cleaners model WUCDO3H by Multi-Frequency Sonication Body (Witeg, Germany). The collected fractions were filtered through Whatman No. 4 filter paper supported by porcelain funnel and Electric aspirator pump 9.5 liter $120 \mathrm{~V} / 60 \mathrm{~Hz}$ Electric aspirator pump model VE-11 of Jeio Tech co.Ltd, Korea), and formerly were stored at room temperature overnight.

Adult female pregnant Swiss Webster strain mice (300-350 g) were purchased from the Animal Center of the Nutrition Department, Medicine School, University of Indonesia (Jakarta, Indonesia). All animal protocols are approved by the Ethical committee of Medicine school, 
University of Indonesia. At the beginning of the experiments, adult female pregnant mice were dissected, which are required to obtain cerebral cortex from fetus at gestation day (GD) 18-19. Cerebral cortex were placed in $3 \mathrm{~mL}$ Cold PBS solution containing $900 \mu \mathrm{l}$ Trypsin-EDTA BIOWEST solution and $100 \mu \mathrm{g} / \mathrm{ml}$ DNase Applichem. thoroughly added $10 \%$ FBS - DMEM BIOWEST. The cell suspension was then incubated for 15 minutes with AUTOFLOW IR Water-Jacketed CO2 Incubator NUARE and fractionated by centrifugation at $300 \mathrm{xg}$ for 3 min with Hitachi Centrifuge Type CT6EL.

Extraction and Isolation: The extractions were performed employing an Rotary evaporator model RV10 of IKA (Werke $\mathrm{GmbH} \& \mathrm{Co} . \mathrm{KG}$, Germany) and Acetone as solvent, in three cycles for 4 hours 6 minutes, at boiling point $60^{\circ} \mathrm{C}$, rotation 100rpm, Vacuum $556 \mathrm{mBar}$, efficiency $80 \%$, evaporation enthalpy $513 \mathrm{~J} / \mathrm{g}$, density $784 \mathrm{Kg} / \mathrm{m}^{3}$. Then, an extraction/ elution stage was performed employing N-Hexane at boiling point $60^{\circ} \mathrm{C}$, rotation $100 \mathrm{rpm}$, Vacuum $335 \mathrm{mBar}$, efficiency $80 \%$, evaporation enthalpy $368 \mathrm{~J} / \mathrm{g}$, density $660 \mathrm{Kg} / \mathrm{m}^{3}$; in this case, in three cycles for $2 \mathrm{~h} 55 \mathrm{~min}$. The extract was kept in brown bottle and stored in $-30^{\circ} \mathrm{C}$ BioMedical Freezer Model LBF-4010U (DAIHAN LABTECHCO.,LTD, Korea) for 48 hours. The pale yellow crystal was lyophilized using FreeZone 1 Liter Benchtop Freeze Dry System Catalog \# 7740030 (Labconco Kansas City Missouri, USA) until extending to a stable weight (approximately $80 \%$ of the original weight); then it was kept at $4{ }^{\circ} \mathrm{C}$ until the time for the chromatographic analysis was due. In the analysis, a quantity of around $5 \mathrm{mg}$ of sample in methanol was occupied.

The investigated pale-yellow crystal samples were applied using microcapillaries to the thin-layer chromatographic plates, 3 samples per one plate of TLC Silica gel 60 F 25 Glass plates 20 x $20 \mathrm{~cm}$ - Merck Millipore. Samples were spotted onto the plates in the width of $10 \mathrm{~mm}$ from each other and from the left and the right edge of the plate as well as $10 \mathrm{~mm}$ above the lower edge. The chromatograms were developed in the vertical chromatographic chambers to the width of $7 \mathrm{~cm}$ using chloroform-ethyl acetate-formic acid $(2.5: 1: 01, \mathrm{v} / \mathrm{v})$ as the eluent and were visualized in the TLC plate viewing box 022.9160 CAMAG® UV Lamp 4 dual wavelength 254/366 $\mathrm{nm}, 2 \times 8 \mathrm{~W}$ at the wavelength $\mathrm{l}=254 \mathrm{~nm}$. The TLC analyses were repeated three times $(n=3)$ for each investigated sample.

This finding employed Shimadzu HPLC system model RF-10AXL (Shimadzu Corporation, Horiyamashita Hadano Kanagawa, Japan), including: LC-20AB prominence pumps, CTO-20AC prominence column oven, SIL-20AC prominence auto sampler, SPD-20 AV prominence UV/VIS detector, RF-10Axl fluorescence detector, CBM-20A (Lite) controller, DGU-20A5 prominence degasser, and computer integrated LC system software., using a CAPCELL PAK C18 UG120 S5 (SHISEIDO CO.,LTD, Japan) of $4.6 \mathrm{mml} . D$ x $250 \mathrm{~mm}$. The extracts were filtered through nylon filters of $0.45 \mu \mathrm{m}$ pore size. The mobile phase used solvent A (Aqua Pro Injection) and solvent B (Acetonitrile) (60:40; v: v). The flow rate was performed at $1 \mathrm{~mL} / \mathrm{min}$ with linear gradient elution from $10 \%$ of solvent $B$ and $90 \%$ of solvent A within 18 minutes; to $85 \%$ of solvent $B$ and $15 \%$ of solvent $A$ for 5 minutes. The UV detector were adjusted at $1=306 \mathrm{~nm}$; the trans-resveratrol peak appeared after an elution time of 14 minutes fortempeh and 11 minutes for soybean seed coat.

The extraction yield of trans-resveratrol was defined as follows:

yield $(\%)=\frac{\text { Mass of extract in extraction solution }}{\text { Sum of the mass of extract in sample }} 100$

The extraction yield of resveratrol in tempeh was 129 grams divided by 198 grams and multiplied by 100 which was equal to $65.15 \%$. Meanwhile, the extraction yield of resveratrol in soybean seed coat was 109.6 grams divided by 198 grams and multiplied by 100 which were equal to $55.35 \%$.

Cell Culture: Primary cells from the cerebral cortex of fetus mice GD 18-19 were plated on poly-D-Lysine coated dishes in Neurobasal-A GIBCO containing $1 \%$ GlutaMAX-1 GIBCO, $1 \%$ Penicillin-Streptomycin SIGMA, $2 \%$ B-27 Supplement GIBCO, $10 \%$ Fetal Bovine Serum BIOWEST and maintained in this manner for confluent stage at $37{ }^{\circ} \mathrm{C}, 5 \% \mathrm{CO}_{2}$ and $90 \%$ relative humidity. The cells were then harvested by treatment with trypsin-EDTA GIBCO solution.

Biotium MTT assay $100 \mu \mathrm{L}$ of the cell suspension ( 7500 cells) was added into each well of the $3 \mathrm{ml}$ sterile cultures plates and incubated at $37^{\circ} \mathrm{C}, 5 \% \mathrm{CO}_{2}$ and $90 \%$ relative humidity for 7 days. After 7 days, Cell fractions were washed with PBS and changed medium with Neurobasal medium without supplemented material for 2 h. Cells were treated Triple different concentrations (1.4, 2.8 and $4.2 \mu \mathrm{g} / \mathrm{mL}$ ) of Resveratrol (Resveratrol Standard SIGMA, Tempeh and Soybean seed coat) and the plates were incubated for a further period of $60 \mathrm{~min}$ in the $\mathrm{CO}_{2}$ incubator. Cells were washed again with PBS, changed the medium with $500 \mu \mathrm{l}$ Biotium solution $(2 \mathrm{~mL}$ Casein, $10 \mu \mathrm{l} \mathrm{EtBr}$ and $5 \mathrm{~mL}$ PBS $5 \mathrm{~mL}$ ) per sterile petri dish and incubated for 30 minutes. Cells were observed with ZOE, BIO-RAD Microscope Fluorescence.

\section{RESULTS}


Numerous researches have raised the findings of resveratrol because of the enormous potential benefits to human health and these recently conducted works show on Table I (Baur \& Sinclair, 2006). Neither of them can be easily obtained in Indonesia. There is considerable interest in the
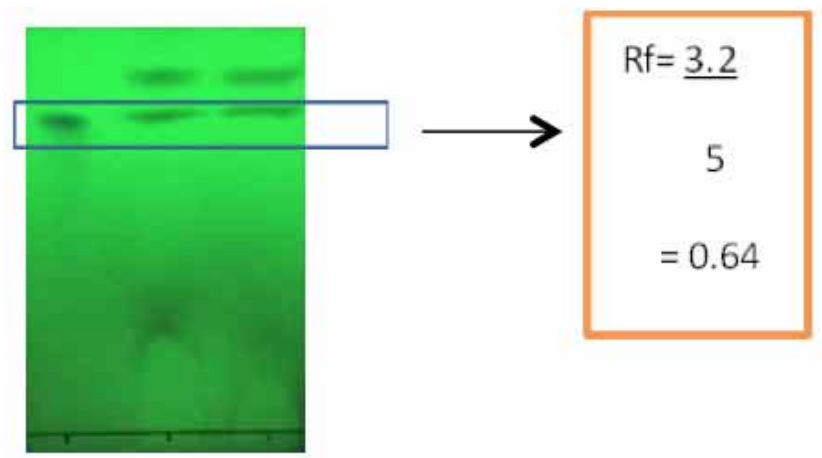

\section{S T SSC}

Fig. 1. TLC analysis [S (Trans-Resveratrol Standard); T (Tempe); SSC (Soybean Seed Coat)] Rf $=0.64$.

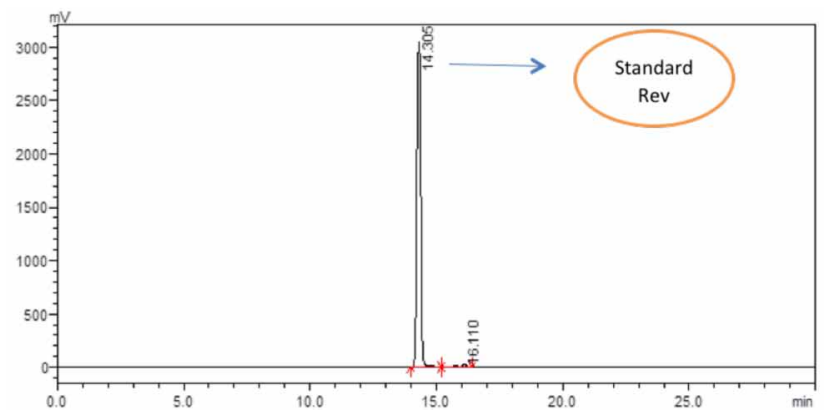

Fig. 2. HPLC analysis S [Trans-Resveratrol Standard] Peak at retention time 14.305 .

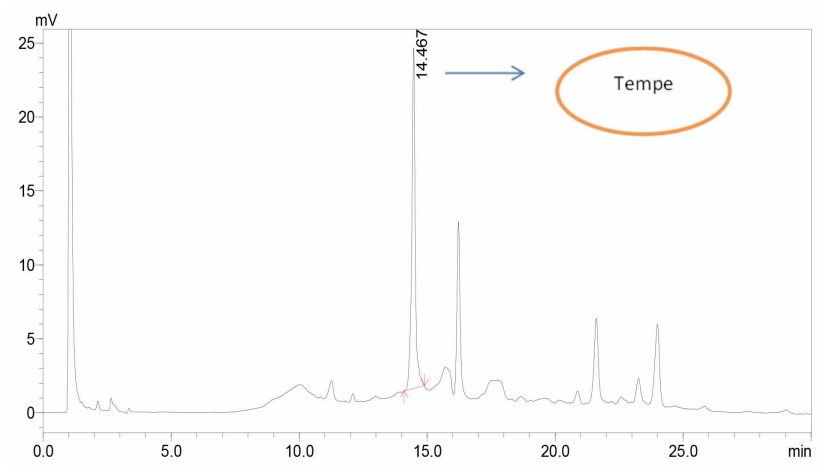

Fig. 3. HPLC analysis T [Tempe] peak at retention time 14.467 min. findings of Resveratrol from Indonesian dietary sources due to the low cost and availability. As a consequence, the findings of resveratrol from tempeh as Indonesian soybean fermented food and soybean seed coat as waste from tempeh making process play an important role in provide a huge number of resveratrol.

It is presumed that the discovery of resveratrol continues until stable trans-form and high concentration is obtained, include research on Polyganum cuspidatum have not clearly defined ways of making sure the concentration and stability of trans-Resveratrol until 2013 (Wang et al., 2013).

A TLC and HPLC method were elaborated for the perseverance of trans-resveratrol in the samples of soybean seed coat and tempeh, Indonesian soybean fermented food. Any point on the resulting surface represents the best separation of the compound at that particular composition of acetone and n-hexane. Thus, the best separation is achieved when the eluent composition for TLC was a mixture of chloroform, ethyl acetate, and formic acid $(2.5+1+0.1, \mathrm{v} /$ v). TLC analysis showed the Rf result 0.64 which is shown in Fig 1.

The spotted parts of these compounds were confirmed by HPLC with acetonitrile and aqua pro injection water as the mobile phase. HPLC analysis also showed a peak with retention time of 14.467 for Tempeh (Figs. 2 and 3) and 11.977 for Soybean Seed Coat (Figs. 4 and. 5).

Biotium MTT assay results showed that Resveratrol (Resveratrol Standard SIGMA, Tempeh and Soybean seed coat) gave prevents the cell to divide in order to undergo cell death by apoptosis (Fig. 7).

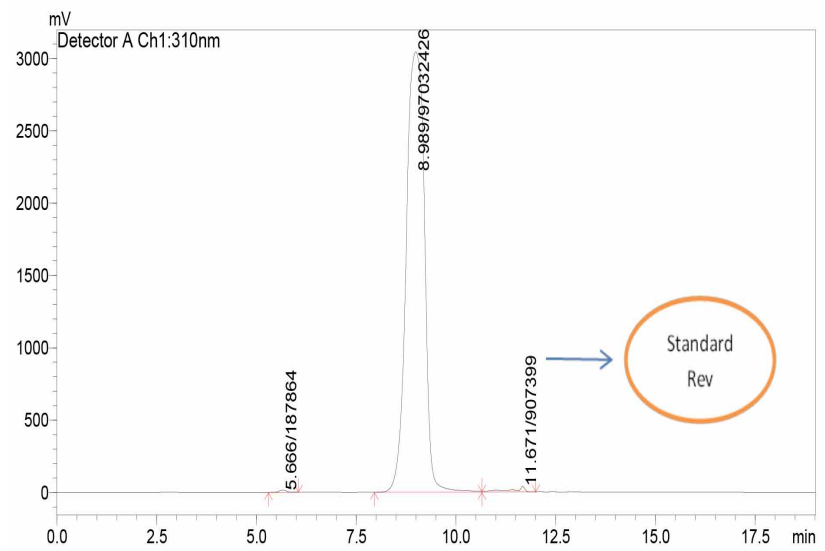

Fig. 4. HPLC analysis S [Trans-Resveratrol Standard] peak at retention time $11.671 \mathrm{~min}$. 
Table I. Findings of Resveratrol (Baur \& Sinclair, 2006).

\begin{tabular}{|c|c|c|c|}
\hline No & Source & trans-Resveratrol Concentration & Note \\
\hline 1 & Red wines & $0.1-14.3 \mathrm{mgl}^{-1}$ & $\begin{array}{l}\text { cis-Resveratrol, trans-Pieced and } c i s \text {-Pieced also present, typically at slightly } \\
\text { lower concentration }\end{array}$ \\
\hline 2 & $\begin{array}{l}\text { White wines Ports } \\
\text { and Sherries }\end{array}$ & $\begin{array}{l}<0.1-2.1 \mathrm{mgl}^{-1} \text { Generally }<0.1 \\
\mathrm{mgl}^{-1}\end{array}$ & $\begin{array}{l}\text { Generally resveratrol found at concentrations of }<0.1 \mathrm{mg} \mathrm{l}^{-1} \text {, exceptions } \\
\text { include Swiss, Portuguese and German Riesling wines, cis-resveratrol, trans- } \\
\text { Pieced and cis-Pieced also present }\end{array}$ \\
\hline 3 & Grapes & $0.16-3.54 \mu \mathrm{g} \mathrm{g}^{-1}$ & $\begin{array}{l}\text { Contents are similar for wine or table grapes, and black or white grapes, trans- } \\
\text { Pieced is predominant at concentrations of } 1.5-7.3 \mu^{-1} g^{-1}\end{array}$ \\
\hline 4 & Dry grape skins & $24.06 \mu \mathrm{g} \mathrm{g}^{-1}$ (Average) & $\begin{array}{l}\text { trans-Pieced and cis-Pieced found at concentrations of } 42.19 \mu \mathrm{g} \mathrm{g}-1 \text { and } 92.33 \\
\mu \mathrm{g} \mathrm{g}^{-1} \text {, respectively }\end{array}$ \\
\hline 5 & Red grape juices & $0.50 \mathrm{mg} \mathrm{l}^{-1}\left(\mathrm{~A}_{\text {verage }}\right)$ & $\begin{array}{l}\text { trans-Pieced, cis-Pieced and cis-Resveratrol found at concentrations of } 3.38 \\
\mathrm{mg} \mathrm{l}^{-1}, 0.79 \mathrm{mg} \mathrm{l}^{-1} \text {, and } 0.06 \mathrm{~m} \mathrm{l}^{-1} \text {, respectively }\end{array}$ \\
\hline 6 & White grape juices & $0.05 \mathrm{mg} \mathrm{l}^{1}\left(\mathrm{~A}_{\text {verage }}\right)$ & $\begin{array}{l}\text { trans-Pieced and cis-Pieced found at concentrations of } 0.18 \mathrm{mg} \mathrm{l}^{-1} \text { and } 0.26 \\
\mathrm{mg} \mathrm{l}^{-1} \text {, respectively }\end{array}$ \\
\hline No & Source & trans-Resveratrol Concentration & Note \\
\hline 7 & Cranberry raw juice & $-0.2 \mathrm{mg} \mathrm{l}^{-1}$ & cis-Resveratrol also found at a concentration of $-0.03 \mathrm{mgl}^{-1}$ \\
\hline 8 & Blueberries & $\mathrm{Up}$ to $\sim 32 \mathrm{ng} \mathrm{g}^{-1}$ & - \\
\hline 9 & Bilberries & Up to $\sim 16 \mathrm{ng} \mathrm{g}^{-1}$ & - \\
\hline 10 & $\begin{array}{l}\text { Other } \quad \text { Vaccinium } \\
\text { berries }\end{array}$ & $7-5,900 \mathrm{ng} \mathrm{g}^{-1}$ (dry sample) & Highest concentrations in lingonberries \\
\hline 11 & Peanuts & $0.02-1.92 \mu \mathrm{gg}^{-1}$ & - \\
\hline 12 & Roasted peanuts & $0.055 \mu \mathrm{g} \mathrm{g}^{-1}$ & - \\
\hline No & Source & trans-Resveratrol Concentration & Note \\
\hline 13 & Boiled peanuts & $5.1 \mu \mathrm{g} \mathrm{g}^{-1}$ & - \\
\hline 14 & Peanut butters & $0.3-0.4 \mu \mathrm{g} \mathrm{g}^{-1}$ (Avarage) & trans-Pieced also found at a concentration of $0.13 \mu \mathrm{g} \mathrm{g}^{-1}$ \\
\hline 15 & $\begin{array}{l}100 \% \text { Natural peanut } \\
\text { butters }\end{array}$ & $0.65 \mu \mathrm{gg}^{-1}$ (Avarage) & trans-Pieced also found at a concentration of $0.14 \mu \mathrm{g} \mathrm{g}^{-1}$ \\
\hline 16 & Pistachios & $0.09-1.67 \mu \mathrm{gg}^{-1}$ & - \\
\hline 17 & $\begin{array}{l}\text { Groundnuts (Arachis } \\
\text { hypogaea) }\end{array}$ & Not Detected & - \\
\hline 18 & Rhubarb & Not Detected & - \\
\hline 19 & Hops & $0.5-1 \mu \mathrm{g} \mathrm{g}^{-1}$ & $\begin{array}{l}\text { trans-Pieced and cis-Pieced also found at a concentration of } 2-9 \mu \mathrm{g} \mathrm{g}^{-1} \text { and } \\
0.9-6 \mu \mathrm{gg}^{-1} \text { respectively }\end{array}$ \\
\hline 20 & $\begin{array}{l}\text { Itadori (Polygonum } \\
\text { cuspidatum) tea }\end{array}$ & $0.68 \mathrm{mg} 1-^{1}$ & trans-Pieced also found at a concentration of $9.1 \mathrm{mg} \mathrm{l}^{1}$ \\
\hline 21 & Veratrum (Lily) & Not Detected & - \\
\hline 22 & $\begin{array}{l}\text { Cassia } \\
\text { quinquangulata }\end{array}$ & Not Detected & - \\
\hline 23 & Gnetum klossii & Not Detected & - \\
\hline 24 & $\begin{array}{l}\text { Polygonum } \\
\text { cuspidatum }\end{array}$ & $0.524 \mathrm{mg} \mathrm{g}^{-1}$ & trans-Pieced also found at a concentration of $1.65 \mathrm{mg} \mathrm{g}^{-1}$ \\
\hline 25 & $\begin{array}{lr}\text { Rhubarb } & \text { (Rheum } \\
\text { rhaponticum) } & \text { dry root }\end{array}$ & $3.9 \mathrm{mg} \mathrm{g}^{-1}$ & - \\
\hline No & Source & trans-Resveratrol Concentration & Note \\
\hline 26 & $\begin{array}{l}\text { Yucca schidigera } \\
\text { Bark }\end{array}$ & Not Detected & - \\
\hline 27 & Peanut roots & Detected & - \\
\hline 28 & $\begin{array}{l}\text { Endophyte-infected } \\
\text { grasses }\end{array}$ & Detected & - \\
\hline 29 & $\begin{array}{l}\text { Pterolobium } \\
\text { hexapetullum }\end{array}$ & Detected & - \\
\hline 30 & Spruce & Detected & - \\
\hline 31 & Eucalyptus & Detected & - \\
\hline 32 & $\begin{array}{l}\text { The heartwood of } \\
\text { mulberry }\end{array}$ & Detected & - \\
\hline 33 & Bauhini a racemosa & Detected & - \\
\hline
\end{tabular}

\section{DISCUSSION}

The trans-resveratrol extraction yields content in tempeh and soybean seed ranged from $65.15 \%$ to $55.35 \%$, respectively. It can be assumed that the phytoalexins are localized in the tissue beneath and close to the site of fungal or bacterial infection (Bennett \& Wallsgrove, 1994). While 


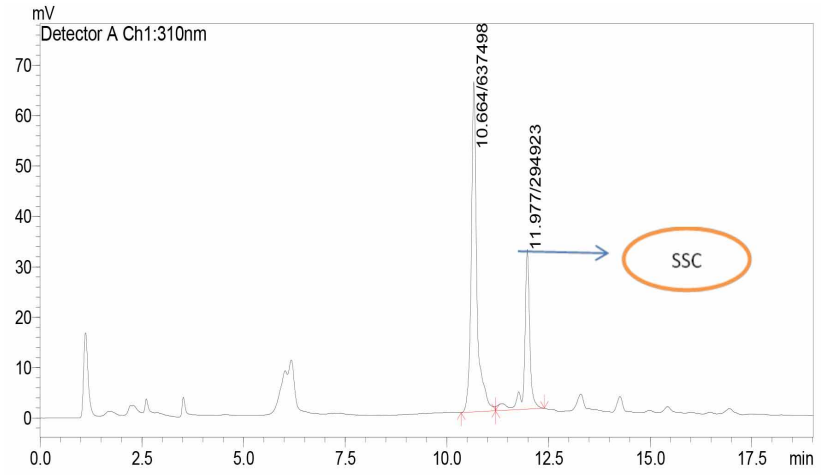

Fig. 5. HPLC analysis SSC [Soybean Seed Coat] peak at retention time $11.977 \mathrm{~min}$
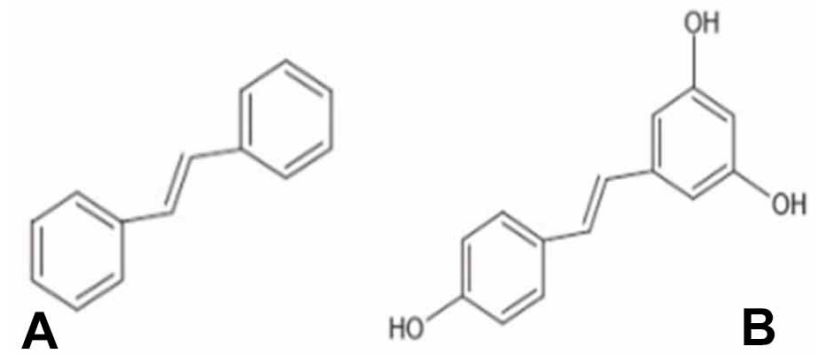

Fig. 6. Chemical Structure of Stilbene (a) and Chemical Structure of Resveratrol(b)

the active response of the plant cell is close to the attempted infection; the second one is the acquisition of resistance by plants after exposure to microorganisms (Jeandet, 2015). Tempeh processes with germination and elicitation by tempeh yeast inoculated in tofu pulp. These proses proposed chemical and enzymatic hydrolysis are affected composition and content of the resveratrol in tempeh. The trans-resveratrol has proven demanding to be isolated using commonly outlined extraction methods mainly because it is wrapped within the plant cell wall, thus it is difficult to damage the cell wall and the extraction yield is low. In these works, sonication and modification maceration were invaluable loose cell walls, reducing the mass transfer resistance and accelerating the release of the active ingredient to obtain trans-resveratrol from tempeh, as Indonesian soybean fermented food, and soybean seed coat.

As mentioned previously resveratrol was barely detected as stilbenic compounds. It exists in plants of several families, such as: Cyperaceae, Dipterocarpaceae, Gnetaceae, Fabaceae, Leguminoseae, Pinaceae, Poaceae, and Vitaceae, and is synthesized from the phenylpropanoid substrates that are present in all higher plants and it also involves the activity of stilbene synthase or resveratrol synthase (STS) (Jeandet). It is possible, for example, that enzymes responsible for resveratrol derivative production may also be secreted into the tempeh media, converting resveratrol into the more potent phytoalexins as part of a plant's immune response. Resveratrol (Fig. 6) or stilbene (Fig 6) with a broad spectrum of biological activities recently generated an interest as nutraceuticals with health promoting effects in humans, such as: cardio protection, anti-inflammatory, neuroprotective and anticancer effects (Singh et al., 2015) and also as antibiotics protecting plants from various microorganisms, nematodes, or herbivores (Jeandet et al., 2013).

Polyphenols, resveratrol has received an extreme pact of scrutiny because this compound may commit to the claimed neuroprotective action of the regular consumption of tempeh. It has been reported that PKC enzymes are involved in the neuroprotective effect of resveratrol against Ab-induced neurotoxicity (Han et al., 2004). In Figures number of 8 and 9 , show that trans-resvertrol compounds from soybean seeds and Soybean seed coat, have the potential to induce proliferation of nerve cell cultures, just as induced by trans-resveratrol standard.
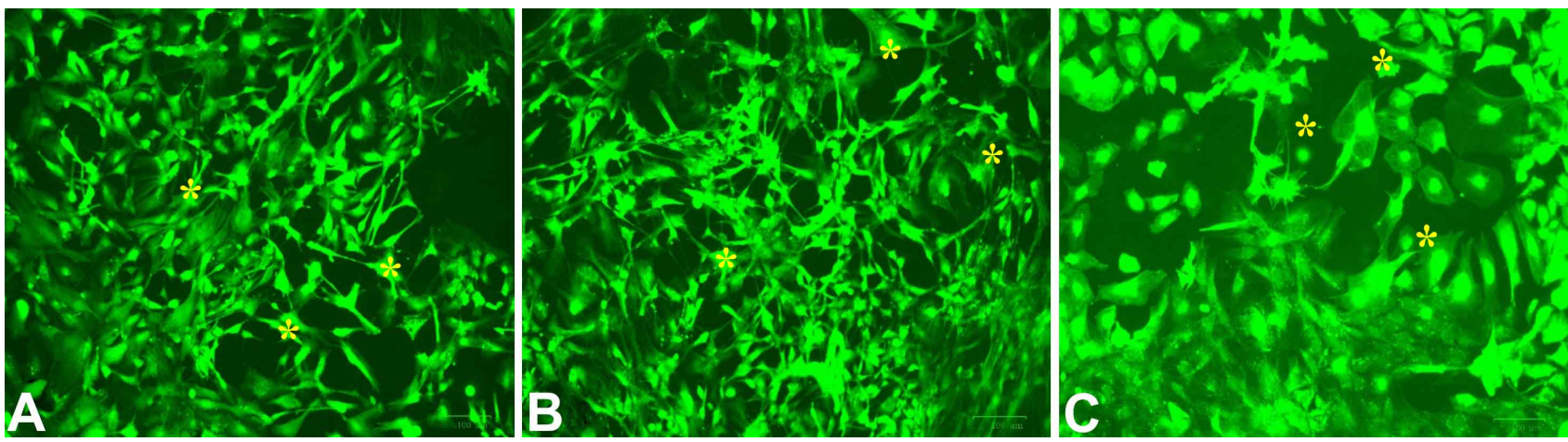

Fig. 7. A. Primary cortical neuron culture after treatment: trans-resveratrol standard $(10 \mathrm{x} 10)$. B. primary cortical neuron culture after treatment: Resveratrol isolated Tempeh $(10 \mathrm{x} 10)$. C. primary cortical neuron culture after treatment: Resveratrol isolated Soybean seed coat $(10 \times 10)^{*}$, yellow stars indicate living neurons. 
Moreover, it postulates that the purported cognitive enhancing properties of polyphenols in memory-impaired animals (Cherniack, 2012) could be due to their stimulatory effects on PKCg activity. These findings support the function of resveratrol as the effects of resveratrol on PKCg activation in hippocampal neuronal cells (Menard et al., 2013). Interestingly, resveratrol increased both phosphorylation and expression of $\mathrm{PKCg}$, suggesting an active role for this enzyme in neuronal cell survival promoted by this polyphenol (Quirion, 2013). PKC signaling is involved in the regulation of multiple signaling pathways (Newton, 2009; Loegering \& Lennartz, 2011). Future studies with novel resveratrol isolated from tempeh as Indonesian soybean fermented food and soybean seed coat will be required to evaluate the specific effect of resveratrol on PKC enzymes, notably PKCg.

Thus, soybean in tempeh and Soybean seed coat resistance to fungal infection is in part a consequence of the plant's ability to develop basal defense responses involving trans-Resveratrol production/accumulation and our data reported here reinforce the role played by fermentation process in plant defense. Our results indicated that fermentation of soybean in tempeh, producing a greater accumulation of trans-Resveratrol in response to general fermented bacteria invasion. The findings were constitutively expressed to determine the trans-Resveratrol on soybean fermentation, it is assumed that it is possible that this result either influenced by unlighted Maceration and Ultrasound Technique or inoculate microorganism at fermentation process.

\section{CONCLUSIONS}

Resveratrol was confirmed by TLC and HPLC analysis applying fluorescence detection and Rf-value for trans-resveratrol is 0.64 . As eluent, a mixture of chloroform, ethyl acetate, and formic acid $(2.5+1+0.1$, $\mathrm{v} / \mathrm{v}$ ) was selected, retention time for tempeh was 14.467 and for soybean seed coat was 11.977. The extraction yield of resveratrol was $65.15 \%$ in tempeh and 55.35 $\%$ in soybean seed coat.

In this research, this compound has been presented to give an overview of plant-derived neuroprotective agents, and isolated from Fermented Soybean (tempeh) \& Soybean seed coat as the alternative sources of Trans-Resveratrol as a natural stilbenoids compound, in addition to has prevented cell death by apoptosis.

\section{ACKNOWLEDGMENTS}

This project is supported by Ministry of Research, Technology and Higher Education of the Republic of Indonesia (Grant contract no : 6/SP2H/DRPM/LPPM-UNJ/II/2018), and we would like to thanks for The Research Center for Biomaterials, Biology and Biotechnology (LIPI) Indonesia; and Chemistry Laboratory of Universitas Negeri Jakarta, Indonesia.

IRNIDAYANTI, Y. \& SUTIONO, D. R.Tempeh y cubierta de semillas de soja: Fuentes alternativas de trans-Resveratrol como agentes neuroprotectores. Int. J. Morphol., 37(3):1164-1171, 2019

RESUMEN: El resveratrol es un estilbenoide, un tipo de fenol natural, y fitoalexina producida por varias plantas en respuesta a una lesión o ataque de hongos. La subutilización de la cubierta de la semilla de soja (Glycine max (L.) Merrill.) y el tempeh, alimento fermentado barato de Indonesia, abren una nueva oportunidad para obtener un medicamento a base de resveratrol para propósitos de desarrollo de agentes neuroprotectores derivados de plantas. En este estudio, se aisló el resveratrol del tempeh, generalmente conocido como alimento fermentado de soja de Indonesia y de la cubierta de la semilla de soja. El hallazgo de este compuesto se confirmó mediante análisis de TLC y HPLC aplicando detección de fluorescencia. A partir de esto, el valor de Rf para trans-resveratrol es 0,64. Como eluyente, se seleccionó una mezcla de cloroformo, acetato de etilo y ácido fórmico $(2,5+1+0,1, \mathrm{v} / \mathrm{v})$. Además, el tiempo de retención para el tempeh fue de 14,467 y para el revestimiento de semilla de soja fue de 11,977. El rendimiento de extracción del resveratrol fue del $65,15 \%$ en tempeh y del $55,35 \%$ en la cubierta de la semilla de soja. El resveratrol aislado de tempeh y de la cubierta de la semilla de soja previno reacciones mediante la modulación de ciertas vías de señalización intracelular: proteína quinasa $\mathrm{C}$ (PKC), una familia de 12 serina/treonin quinasas, proporcionando una nueva molécula de plomo con efectos neuroprotectores, además de prevenir la muerte celular por apoptosis.

PALABRAS CLAVE: Trans-Resveratrol; Tempeh; Cubierta de de semilla de soja; Neuroprotección.

\section{REFERENCES}

Baur, J. A. \& Sinclair, D. A. Therapeutic potential of resveratrol: the in vivo evidence. Nat. Rev. Drug Discov., 5(6):493-506, 2006.

Bennett, R. N. \& Wallsgrove, R. M. Secondary metabolites in plant defence mechanisms. New Phytol., 127(4):617-33, 1994.

Boroski, M.; Mitsui, M. L.; Bulla, M. K.; Donaduzzi, C. M.; Kamei, M. S.; Cortez, L. E. R. \& Cortez, D. A. G. trans-Resveratrol and antioxidant activity of grape (Vitis vinifera $\mathrm{sp}$ ) byproducts. Braz. J. Food Res., 7(3):66-81, 2016. 
Cherniack, E. P. A berry thought-provoking idea: the potential role of plant polyphenols in the treatment of age-related cognitive disorders. $\mathrm{Br} . \mathrm{J}$. Nutr, 108(5):794-800, 2012.

Dueñas, M.; Hernández, M. T.; Robredo, S.; Lamparski, G., Estrella, I. \& Muñoz, R. Bioactive phenolic compounds of soybean (Glycine max cv. Merit): modifications by different microbiological fermentations. Pol. J. Food Nutr. Sci., 62(4):241-50, 2012.

Han, Y. S.; Zheng, W. H.; Bastianetto, S.; Chabot, J. G. \& Quirion, R. Neuroprotective effects of resveratrol against beta-amyloid-induced neurotoxicity in rat hippocampal neurons: involvement of protein kinase C. Brit. J. Pharmacol., 141(6):997-1005, 2004.

Jasin'ski, M.; Jasinska, L. \& Ogrodowczyk, M. Resveratrol in prostate diseases - a short review. Cent. European J. Urol., 66(2):144-9, 2013.

Jeandet, P. Phytoalexins: current progress and future prospects. Molecules, 20(2):2770-4, 2015.

Jeandet, P.; Clément, C.; Courot, E. \& Cordelier, S. Modulation of phytoalexin biosynthesis in engineered plants for disease resistance. Int. J. Mol. Sci., 14(7):14136-70, 2013.

Kennedy, D. O.; Wightman, E. L.; Reay, J. L.; Lietz, G.; Okello, E. J.; Wilde, A. \& Haskell, C. F. Effects of resveratrol on cerebral blood flow variables and cognitive performance in humans: a double-blind, placebo-controlled, crossover investigation. Am. J. Clin. Nutr. 91(6):1590-7, 2010.

Lee, B. H.; Hwang, S. H.; Choi, S. H.; Shin, T. J.; Kang, J.; Lee, S. M. \& Nah, S. Y. Resveratrol enhances 5-hydroxytryptamine type 3A receptor-mediated ion currents: the role of arginine 222 residue in pretransmembrane domain I. Biol. Pharm. Bull., 34(4):523-7, 2011.

Loegering, D. J. \& Lennartz, M. R. Protein kinase C and toll-like receptor signaling. Enzyme Res., 2011:537821, 2011.

Menard, C.; Bastianetto, S. \& Quirion, R. Neuroprotective effects of resveratrol and epigallocatechin gallate polyphenols are mediated by the activation of protein kinase C gamma. Front. Cell. Neurosci., 7:281, 2013.

Newton, A. C. Protein kinase C: poised to signal. Am. J. Physiol. Endocrinol. Metab., 298(3):E395-402, 2009.

Piñeiro, Z.; Palma, M. \& Barroso, C. G. Determination of trans-resveratrol in grapes by pressurised liquid extraction and fast high-performance liquid chromatography. J. Chromatogr. A, 1110(1-2):61-5, 2006.

Qin, Y.; Ma, Z.; Dang, X.; Li, W. \& Ma, Q. Effect of resveratrol on proliferation and apoptosis of human pancreatic cancer MIA PaCa-2 cells may involve inhibition of the Hedgehog signaling pathway. Mol. Med. Rep., 10(5):2563-7, 2014.

Singh, C. K.; Ndiaye, M. A. \& Ahmad, N. Resveratrol and cancer: Challenges for clinical translation. Biochim. Biophys. Acta, 1852(6);1178-85, 2015.

Turner, R. S.; Thomas, R. G.; Craft, S.; van Dyck, C. H.; Mintzer, J.; Reynolds, B. A.; Brewer, J. B.; Rissman, R. A.; Raman, R.; Aisen, P. $\mathrm{S} . ;$ et al. A randomized, double-blind, placebo-controlled trial of resveratrol for Alzheimer disease. Neurology, 85(16):1383-91, 2015.

Vingtdeux, V.; Giliberto, L.; Zhao, H.; Chandakkar, P.; Wu, Q.; Simon, J. E.; Janle, E. M.; Lobo, J.; Ferruzzi, M. G.; Davies, P.; et al. AMPactivated protein kinase signaling activation by resveratrol modulates amyloid-beta peptide metabolism. J. Biol. Chem., 285(12):9100-13, 2010.

Wang, D. G.; Liu, W. Y. \& Chen, G. T. A simple method for the isolation and purification of resveratrol from Polygonum cuspidatum. J. Pharm. Anal., 3(4):241-7, 2013.

Wenzel, E. \& Somoza, V. Metabolism and bioavailability of transresveratrol. Mol. Nutr. Food Res., 49(5):472-81, 2005.

Zhao, Y. N.; Li, W. F.; Li, F.; Zhang, Z.; Dai, Y. D.; Xu, A. L.; Qi, C.; Gao, J. M. \& Gao, J. Resveratrol improves learning and memory in normally aged mice through microRNA-CREB pathway. Biochem. Biophys. Res. Commun., 435(4):597-602, 2013.

\author{
Corresponding author: \\ Yulia Irnidayanti \\ Departement of Biology \\ Faculty of Mathematics and Science \\ Universitas Negeri Jakarta \\ Hasyim Asyarie Buildin \\ Rawamangun muka \\ INDONESIA
}

Email: yirnidayanti@unj.ac.id

Received: 24-01-2019

Accepted:01-03-2019 